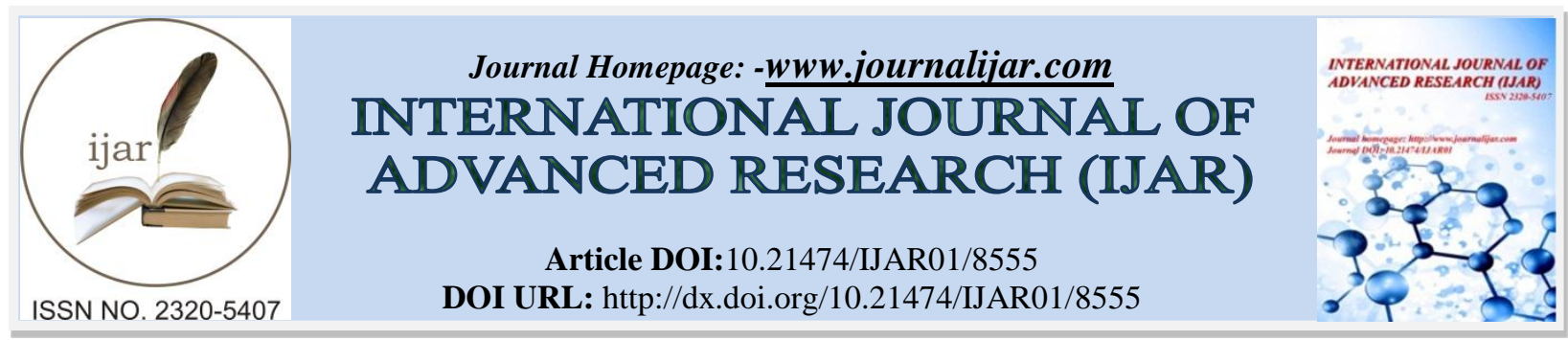

RESEARCH ARTICLE

\title{
PARENT'S SATISFACTION OF FREE SENIOR HIGH SCHOOL POLICY IN THE ASUNAFO SOUTH DISTRICT IN THE BRONG - AHAFO REGION OF GHANA.
}

Addae Amoako Michael ${ }^{1}$, Affi Osei Prince ${ }^{2}$ and Boakye Boateng Michael ${ }^{3}$.

1. Department of Political Science, University of Ghana.

2. Department of Statistics, University of Ghana.

3. Centre for Climate Change and Sustainability Studies, University of Ghana.

\section{Manuscript Info}

Manuscript History

Received: 14 December 2018

Final Accepted: 16 January 2019

Published: February 2019

Key words:-

Enrollment, Satisfaction, Parents,

Education, Secondary, Policy.

\section{Abstract}

Education is deemed as one key factor that empowers individuals, and has the ability of breaking the cycle of poverty and reduces inequality among people (SDG Report 2017). Attaining Quality Education in a country will greatly enhance the chances of achieving other Sustainable Development Goals like No Poverty and Reduced Inequalities. Therefore, in line with the Sustainable Development Goals, Ghana government has taken the initiative to make Senior High School (SHS) education free to all Ghanaians. However, many people including high academic figures, educationalists, researchers and some institutions have contested free secondary education in Ghana. Therefore, using quantitative approach and a descriptive research design, this study explores the satisfaction of parents to Ghana's free SHS policy. The study indicated that poor and less educated parents are highly satisfied with the free SHS policy.

Copy Right, IJAR, 2019,. All rights reserved.

\section{Introduction:-}

Education has been considered as one of the key areas or sectors that national development hinges. International recognition has been illuminated the desirable nature of the sector. The sustainable Development Goals (SDG) which came to effect in January 2016 adopted by 193 countries including Ghana in its goal 4 opines inclusive and quality education for all and promotes lifelong learning because education is seen as breaking the cycle of poverty and reduces inequality (SDG Report 2017).

Ghana has been a regional leader in the delivery of Education for All (EFA) reaching the Millennium Development Goal (MDG) goal on education ahead of time in 2015. In 2016, net enrolment reached $92 \%$ at the primary level and $50 \%$ at the Junior High School (JHS) level. But transition to the Senior High School (SHS), many do not benefit from that level of education (SDG 2017-Ghana).

Anti (2017) found out that globally, the EFA target was not met particularly in Ghana at the SHS level. An average of $27.3 \%$ of students who were placed by the Computerised School Selection and Placement system (CSSPS) did not enroll. This was attributed to the problem of access. We believe this may be due to the inability of parents to pay their wards school fees.

Corresponding Author:-Addae Amoako Michael.

Address:-Department of Political Science, University of Ghana. 
Households may want to prioritise education of their children and not to engage in other economic activities which will deter them from schooling. The cost of schooling may be significant barrier to improving educational attainment among poor households in developing countries. Consequently government all over the world have attempted to enact policies to reduce cost associated with education at the household level. Government has made effort to make education free. (Alloush2010).

School fees is a significant obstacle to enrolment especially the poor and the vulnerable. Abolition of fees will make it easier and less costly for children with these challenging backgrounds to enroll in schools. Abolition of fees has a positive correlation with enrolment (ISSER 2009).

Djangbah (2011) argues that majority of poor children are unable to reach JHS hence less chance to transit into the Senior High Schools. His study on the use of Criterion Reference Test, National Education Assessment, Basic Education Certificate Examination (BECE) and West African Secondary School Certificate Examination (WASSCE) found out that private and public basic schools is so wide that in a competitive BECE, most of the places in Ghana's top SHS which was mostly public takes up products of private basic schools which are fee paying. This trend has continued in dividing the SHS schools into elite or grade 'A' schools which has a high chance of progression in the tertiary compared to the less endowed grade schools who are mostly dominated by unprivileged in the society.

Government of Ghana is aware of the quality gap in the school system which is a mirror of the socio-economic gap in a society between the affluent minority and the poorer majority. This is evidenced in the categorisation of public SHS into grade A,B,C and D by the Ghana Education Service which is purely based on the progression of students to the tertiary level, infrastructural development which are mostly provided by the Parents Teacher Association (PTA) in the schools.

Ghana has a history of policy interventions in the educational sector which has influenced enrolment positively. The capitation grant and the school feeding program instituted in 2005 have led to massive enrolment because parents were no longer paying school fees at the public primary and JHS level. To emulate the enrolment in the basic level, the government instituted the free SHS to cover cost of all students including day and boarding. This policy aimed to increase enrolment, improve the standard of education thus ensure its quality and reduce the burden of parents from paying their children school fees (Abdul-Raman et al, 2018).

The free SHS policy was instituted to absorb the cost of day and boarding fees. The cost component of the free SHS policy which is our focus is found below:

\begin{tabular}{|c|c|c|}
\hline SHS FEE ITEMS & DAY & BOARDING \\
\hline Recurrent fee items & 101.47 & 105.47 \\
\hline One-time fee items for only $1^{\text {st }}$ year students & 435.00 & 438.00 \\
\hline Teaching and learning support only for TVET students & 100.00 & 100.00 \\
\hline Feeding fees & 112.00 & 459.20 \\
\hline Grand total-SHS & 648.47 & 1002.67 \\
\hline Grand total- TVET & 748.47 & 1102.67 \\
\hline
\end{tabular}

Source: Ministry of Education

According to Bhalotra, Harttgen and Klassen (2015) school fees hinders enrolment making it hard for parents who are not affluent to send their children to school. Absorbing cost may affect positively, school attendance of the poor. It is evidenced in their study that there is a positive correlation between fee payment and school attendance or enrolment thus abolition of school fees led to massive enrolment in schools.

We believe free SHS in Ghana has resulted adequately to massive enrolment since its inception in September 2017 both in the JHS and the SHS level.

Enrolments trend:

\begin{tabular}{|l|l|l|l|l|l|}
\hline Year & $\begin{array}{l}\text { Total registered } \\
\text { (BECE) }\end{array}$ & $\begin{array}{l}\text { Number placed } \\
\text { in SHS }\end{array}$ & $\begin{array}{l}\text { Number } \\
\text { enrolled in SHS }\end{array}$ & $\begin{array}{l}\text { Number placed } \\
\text { but not enrolled }\end{array}$ & $\begin{array}{l}\% \text { placed but } \\
\text { not enrolled }\end{array}$ \\
\hline
\end{tabular}




\begin{tabular}{|l|l|l|l|l|l|}
\hline 2013 & 391032 & 352202 & 261598 & 90604 & $25.7 \%$ \\
\hline 2014 & 422946 & 386412 & 273152 & 113260 & $29.3 \%$ \\
\hline 2015 & 440469 & 415012 & 299649 & 115363 & $27.8 \%$ \\
\hline 2016 & 461009 & 420135 & 308799 & 111336 & $26.5 \%$ \\
\hline 2017 & 468060 & 424224 & 361771 & 62453 & $14.7 \%$ \\
\hline 2018 projection & 521710 & 497610 & 472730 & 24880 & $5.0 \%$ \\
\hline
\end{tabular}

Source: Ministry of Education

ISSER (2009) report states that school fees contribute to reduction in direct cost of education but is not absolute which means it does not necessarily relieve all cost associated with education. Other cost may be expended on including transportation to and from school, textbooks and teacher motivation paid by parents. So in dealing with free education, there should be a holistic absorption of all components of cost but not to concentrate on only fees. However, some scholars, people including parents and civil society organisations in Ghana including SEND-Ghana and even some government officials have questioned the sustainability of the free SHS policy due to inadequate funds and weak economic base of the country. The government has responded severally with the use of the oil money (petroleum proceeds) and the establishment of Voluntary Education Fund (VEF) to finance the free SHS but not to the satisfaction of many. Some opponents of the free shs policy have proposed the payment of fees of those who can afford. The free SHS policy should be pro poor policy targeting the poor in the society but not to be all inclusive of students from varied family back ground hence the need to target the implementation.

A Graphic/Stanbic breakfast forum cited in graphic online with a theme "financing free quality education in Ghanasustainable quality options" agreed that the rich parents must be made to pay for the education of their children under the free SHS programme to help save the policy from collapsing or compromising the quality of education. Views expressed at the forum indicated that the public funding alone could not sustain the programme hence the need for endowed parents to fund education of their wards which could ensure equity.

According to Djangmah (2011), unless the poorest are identified for enhanced special assistance to remove the direct and indirect cost of education, the additional cost which must go into quality improvement will be wasted on many parents who hardly need assistance. This should inform policy makers to change their rhetoric of free education for all. Educational policies should not be viewed as populist by politicians to endanger the quality of Ghana's educational system. The payment of fees for the academic year should be on needs basis so that those who come from poor background gets more to enable them catch up with those of richer backgrounds.

It is in these line of arguments which is; increased enrolment since the inception of free SHS as against the call for individual funding of education; has aroused our interest to study whether parents supports government funding of the free SHS or it should be parents responsibility and whether it has brought financial relieve as envisioned in the free SHS policy in Asunafo south district and finally whether parents are satisfied with the free SHS policy.

\section{Methodology:-}

The main aim of this study is to assess the satisfaction of parents with the free SHS policy in terms of funding and financial relieve it has brought to parents. The study was conducted in a district located in the western part of Brong Ahafo region specifically Asunafo south. A sample size of 250 respondents was considered and their views sought for using a convenient sampling technique. Parents whose wards enjoy free SHS in the district were our target population. We employed a cross sectional study design using quantitative methodology. The survey was done using questionnaire both open and closed ended in collecting the views of the respondents (primary data). The data was entered into SPSS version 16. All the 250 responses were analysed using descriptive statistics. Cross tabulations and Pearson chi-square test of independence was used in studying the following relationships: educational level and occupation to satisfaction of free SHS; marital status and satisfaction of free SHS; amount spent on children and satisfaction of free SHS; and the number of children enjoying free SHS and satisfaction.

\section{Pearson Chi-Square Test of Independence}

The chi - square test of independence is used to study if there is a significant relationship between two nominal (categorical) variables. The frequency of each category for one nominal is compared across the categories of the second nominal variable. The data is displayed in a contingency table where each row and column represents a category for the other variable. The chi - square test of independence value is given by: 
$\chi^{2}=\sum_{i=1}^{r} \sum_{j=1}^{c} \frac{\left(O_{i j}-E_{i j}\right)^{2}}{E_{i j}}$

Where $O_{i j}$ is the observed value of two nominal variables and $E_{i j}$ is also the expected value of two nominal variables but

$E_{i j}=\frac{\sum_{k=1}^{c} O_{i j} \sum_{k}^{r} O_{i k}}{N}$

Where $\sum_{k=1}^{c} O_{i j}$ is the sum of the $\mathrm{i}^{\text {th }}$ column $\sum_{k}^{r} O_{i k}$ is also the $\mathrm{k}^{\text {th }}$ row and $\mathrm{N}$ is the total number.

The degree of freedom is given by $\mathrm{DF}=(\mathrm{r}-1)(\mathrm{c}-1)$ where $\mathrm{r}=$ number of rows and $\mathrm{c}=$ number of columns.

\section{Results and discussion:-}

\section{Results}

A total number of 250 questionnaires were answered. 141 representing $56.4 \%$ were males and 109 representing $43.6 \%$ were females. 175 respondents representing 70 percent are said to be single, 12 representing 4.8 are married and 63 representing 25.2 percent are divorced.

The educational level of parents was ascertained. The data we gathered indicates that 104 respondents representing 41.6 percent are junior high school or middle school leavers, 61 representing 24.4 percent are SHS leavers. Those who have had tertiary education were 40 representing 16.0 percent and 42 respondents representing 16.8 percent have not attended school before.

Asunafo south have different towns and we wanted to find out how the free SHS has drawn students from these towns to school because boarding of students is essential feature of the components of the free SHS which has motivated enrolment. Out of the 250 respondents, 90 representing 36 percent resides in Kukuom which is one of the biggest towns and happens to be the district capital followed by 52 respondents from Sankore representing 20.8 percent and the rest of the town representing $43.2 \%$.

Table 1:-Socio - Demographic Characteristics of Parents

\begin{tabular}{|c|c|c|c|}
\hline Variables & Frequency & Percent & Cumulative percent \\
\hline \multicolumn{4}{|l|}{ Gender } \\
\hline Male & 141 & 56.4 & 56.4 \\
\hline Female & 109 & 43.6 & 100 \\
\hline \multicolumn{4}{|c|}{ Marital Status } \\
\hline Single & 175 & 70.0 & 70.0 \\
\hline Married & 12 & 4.8 & 74.8 \\
\hline Divorce & 63 & 25.2 & 100 \\
\hline \multicolumn{4}{|c|}{ Educational Level } \\
\hline JHS/Primary & 104 & 41.6 & 41.6 \\
\hline SHS & 61 & 24.4 & 66.0 \\
\hline Tertiary & 40 & 16.0 & 82.0 \\
\hline None & 42 & 16.8 & 98.8 \\
\hline Other & 3 & 1.2 & 100 \\
\hline \multicolumn{4}{|l|}{ Occupation } \\
\hline Farming & 136 & 54.4 & 54.4 \\
\hline Trading & 75 & 30.0 & 84.4 \\
\hline Teaching & 13 & 5.2 & 89.6 \\
\hline Other & 26 & 10.4 & 100 \\
\hline \multicolumn{4}{|c|}{ Place of Residence } \\
\hline Kukuom & 90 & 36.0 & 36.0 \\
\hline Sankore & 52 & 20.8 & 56.8 \\
\hline
\end{tabular}




\begin{tabular}{|llcc|}
\hline Abuom & 19 & 7.6 & 64.4 \\
Nobekaw & 31 & 12.4 & 76.8 \\
Asufufuo & 4 & 1.6 & 78.4 \\
Camrykrom & 10 & 4.0 & 82.4 \\
Yankye & 6 & 2.4 & 84.8 \\
Siana & 6 & 2.4 & 87.2 \\
Anwiam & 6 & 2.4 & 89.6 \\
Dantano & 4 & 1.6 & 91.2 \\
Kwapong & 16 & 6.4 & 97.6 \\
Mfrekrom & 6 & 2.4 & 100 \\
& & & \\
Age & 74 & 29.6 & 29.6 \\
$30-40$ & 73 & 29.2 & 58.8 \\
$41-50$ & 80 & 32.0 & 90.8 \\
$51-60$ & 23 & 9.2 & 100 \\
$61-$ above & & & \\
\hline
\end{tabular}

There is a contention as to the sustainability of the free SHS due to inadequate financial resources to cater for the policy so there is the argument that, parents should fund for their wards fees, so we asked the parents whether government should solely bear the cost or parents should, and 232 of the respondents representing 92.8 accepts that government should fund the free SHS policy with reasons that firstly, it will help children to learn hard; again, it will help swell enrolment; also, it will create opportunity for schooling; moreover, reduction of financial burden of parents; and ensure quality of education with 10 respondents representing 4.0 percent, 13 representing 5.2 percent, 71 representing 28.4 percent, 115 representing 46.0 percent and 7 representing 2.8 percent respectively. The rest of the respondents representing 13.6 percent never gave reasons.

However, 14 respondents representing 5.6 percent said parents should fund for their wards educational expenses.

We also wanted to ascertain whether the intervention of the policy has reduced financial burden of parents in Asunafo south district to assess the intent of the policy so we questioned parents the amount they spend on children with free SHS and those without free SHS. The results showed that 60 respondents representing 24 percent which recorded the highest in response spend GHC 301-500 on each child enjoying free SHS.

With another highest respondent of 93 representing 37.2 spend GHC 1201-1500 on children not enjoying free SHS. This shows that parents spend less with free SHS policy.

The free SHS has increased enrolment from the data from the Ministry of Education but has significantly illuminated problems in public schools such as inadequate infrastructure which includes inadequate furniture, students accommodation etc. so we wanted to find out from parents their level of satisfaction with the policy.

The results show that 122 respondents representing $48.8 \%$ were very highly satisfied, 94 representing 37.6 showed high satisfactions. 15 respondents representing 6.0 indicated low satisfaction, and 6 representing 2.4 indicated very low satisfaction.

These results indicate parents' happiness and satisfaction with the free SHS policy because it has reduced the financial burden attributed by 92 respondents representing 36.8 percent. 21 respondents representing 8.4 percent indicated their unhappiness and dissatisfaction with the policy. Out of 21respondents, 14 attributed their reason to the reduction of quality of education.

Table 2:-

\begin{tabular}{|lccc|}
\hline Variable & frequency & percent & cumulative percent \\
\hline Government funding of SHS & & & \\
\hline Yes & 232 & 92.8 & 92.8 \\
\hline No & 14 & 5.6 & 98.4 \\
\hline Missing & 4 & 1.6 & 100 \\
\hline Reasons for government funding & & & \\
\hline
\end{tabular}




\begin{tabular}{|c|c|c|c|}
\hline Help children to learn hard & 10 & 4.0 & 4.0 \\
\hline Helps enrolment drive in SHS & 13 & 5.2 & 9.2 \\
\hline Create opportunity for schooling & 71 & 28.4 & 37.6 \\
\hline Reduces financial burden of parents & 115 & 46.0 & 83.6 \\
\hline Ensure quality education & 7 & 2.8 & 86.4 \\
\hline Missing & 34 & 13.6 & 100 \\
\hline \multicolumn{4}{|l|}{ Number of children by parents } \\
\hline $1-3$ & 120 & 48 & 48 \\
\hline $4-5$ & 92 & 36.8 & 84.8 \\
\hline 6-7 & 18 & 7.2 & 92 \\
\hline $8-10$ & 20 & 8.0 & 100 \\
\hline \multicolumn{4}{|c|}{ Children who are beneficiaries of free SHS } \\
\hline None & 26 & 10.4 & 10.4 \\
\hline $1-3$ & 212 & 84.8 & 95.2 \\
\hline Missing & 12 & 4.8 & 100 \\
\hline \multicolumn{4}{|c|}{ Amount spend on free SHSstudents per term } \\
\hline \multicolumn{4}{|l|}{ GHC } \\
\hline $0-100$ & 42 & 16.8 & 16.8 \\
\hline $101-300$ & 52 & 20.8 & 37.6 \\
\hline $301-500$ & 60 & 24.0 & 61.6 \\
\hline $501-800$ & 58 & 23.2 & 84.8 \\
\hline Missing & 38 & 15.2 & 100 \\
\hline \multicolumn{4}{|c|}{ Amount spend on non-beneficiaries of free SHS } \\
\hline \multicolumn{4}{|l|}{ GHC } \\
\hline $0-300$ & 19 & 7.6 & 7.6 \\
\hline $301-600$ & 32 & 12.8 & 20.4 \\
\hline $601-900$ & 32 & 12.8 & 33.2 \\
\hline $901-1200$ & 28 & 11.2 & 44.4 \\
\hline $1201-1500$ & 93 & 37.2 & 81.6 \\
\hline Missing & 46 & 18.4 & 100 \\
\hline \multicolumn{4}{|l|}{ Level of satisfaction } \\
\hline Very high & 122 & 48.8 & 48.8 \\
\hline High & 94 & 37.6 & 86.4 \\
\hline Low & 15 & 6.0 & 92.4 \\
\hline Very low & 6 & 2.4 & 94.8 \\
\hline Missing & 13 & 5.2 & 100 \\
\hline \multicolumn{4}{|l|}{ Reasons for satisfaction } \\
\hline Help children to learn hard & 15 & 6.0 & 6.0 \\
\hline Increases enrolment & 16 & 6.4 & 12.4 \\
\hline Creates opportunities of for schooling & 18 & 7.2 & 19.6 \\
\hline Reduces financial burden on parents & 92 & 36.8 & 56.4 \\
\hline Ensure quality education & 10 & 4.0 & 60.4 \\
\hline Reduce quality education & 14 & 5.6 & 66.0 \\
\hline Missing & 85 & 34.0 & 100 \\
\hline
\end{tabular}

The effect of educational level on satisfaction of free SHS policy

To investigate into the effect of educational level on satisfaction of free SHS policy by parents, it was observed that 91 out of the 237 parents who provided information on their educational status had education up to the JHS level and of this $87 \%$ of the parents had a high level of satisfaction of free SHS policy, whiles $13 \%$ of the parents had low satisfaction level of free SHS policy. For parents who had SHS as their higher level of education constituting 61 respondents, $97 \%$ of them had a higher level of satisfaction for the free SHS policy whiles 3\% had a low level of 
satisfaction. For parents who had tertiary qualification constituting 40 respondents, $95 \%$ had a higher level of satisfaction of the free SHS policy and 5\% had low level of satisfaction. Finally the non-educated parents consisting 42 respondents, $95 \%$ showed a high satisfaction but $5 \%$ showed low satisfaction.

From Table 3 below the test is significant $(\mathrm{P}-$ value $=0.000<0.05)$ that is to say parents educational level has impact on parent satisfaction on free SHS policy.

Table 3:-Test of association between educational level and satisfaction of free SHS policy

\begin{tabular}{|l|l|l|l|}
\hline \multirow{2}{*}{ Educational level of Parents } & \multicolumn{2}{|l|}{ Satisfaction level of free SHS policy } & \multirow{2}{*}{ Total } \\
\cline { 2 - 4 } & High & Low & \\
\hline JHS/Middle & 79 & 12 & 91 \\
\hline SHS & 59 & 2 & 61 \\
\hline Tertiary & 38 & 2 & 40 \\
\hline None & 43 & 2 & 45 \\
\hline Total & 219 & 18 & 237 \\
\hline \multicolumn{2}{|c|}{$P-$ value $=0.000$} & \\
\hline
\end{tabular}

\section{The effect of occupation on the satisfaction of free SHS policy}

To also look at occupation on the satisfaction of free SHS by parents, it was observed that farmers were 132 out of 237 who provided information on their occupation and satisfaction level. $92 \%$ of farmers indicated a high level of satisfaction whiles $8 \%$ had low satisfaction. 66 respondents were traders out which $88 \%$ showed high satisfaction and $12 \%$ showed low satisfaction. Teachers among the respondents were 13 which all of them indicated high level of satisfaction which is $100 \%$.

From the table 4 below the test is significant $(\mathrm{P}-$ value $=0.003<0.05)$ that is to say parents occupation has impact on their satisfaction of the free SHS policy.

Table 4:-Test of association between occupation and satisfaction of free SHS policy

\begin{tabular}{|l|l|l|l|}
\hline \multirow{2}{*}{ Occupation of Parents } & Satisfaction level of free SHS policy & \multirow{2}{*}{ Total } \\
\cline { 2 - 4 } & High & Low & \\
\hline Farming & 121 & 11 & 132 \\
\hline Trading & 58 & 8 & 66 \\
\hline Teaching & 13 & 0 & 13 \\
\hline Other & 24 & 2 & 26 \\
\hline Total & 216 & 21 & 237 \\
\hline$\chi^{2}=25.192$ & & \\
\hline
\end{tabular}

$\chi^{2}=25.192 \quad P-$ value $=0.003$

The effect of marital status on satisfaction of free SHS policy

We had 237 respondents showing their marital status and satisfaction. Single parents who constituted 162 of the respondents, $87 \%$ indicated a high satisfaction of the policy and $13 \%$ showing low satisfaction. Out of the 12 respondents who are married, $100 \%$ showed a high level of satisfaction and the divorced who were 63 , they all showed high satisfaction representing $100 \%$.

From the table 5 below, the test is significant $(\mathrm{P}-$ value $=0.011<0.05)$ that is to say parents marital status has impact on their level of satisfaction of the free SHS policy.

Table 5:-Test of association between marital status and satisfaction of free SHS policy.

\begin{tabular}{|l|l|l|l|}
\hline \multirow{2}{*}{ Marital status of Parents } & Satisfaction level of free SHS policy & Total \\
\cline { 2 - 4 } & High & Low & 162 \\
\hline Single & 141 & 21 & 12 \\
\hline Darried & 12 & 0 & 63 \\
\hline Total & 63 & 0 & 237 \\
\hline
\end{tabular}

$\chi^{2}=16.519 \quad P-$ value $=0.011$




\section{The effect on amount spends on children who are non- beneficiaries of free SHS policy and satisfaction}

Out of the 191 parents who responded amount of money they spend on their children who do not enjoy the free SHS policy, 10 who spend 0-300 showed a 100\% high level of satisfaction. 32 parents who spend 301-600 showed another 100\% high level satisfaction. Again, 32 respondents who spend 601-900 on children, 94\% showed high level satisfaction and 6\% showing low level of satisfaction. Parents who spend 901-1200 on their wards, $100 \%$ also showed a high level of satisfaction. Parents consisting of $82 \%$ showed a high level of satisfaction and $18 \%$ showing low level of satisfaction out of 93 parents.

From the table 7 below, the test is significant $(\mathrm{P}-$ value $=0.000<0.05)$ that is to say the amount spent on nonbeneficiary students by parents has an impact on the level of satisfaction.

Table 7:-test of amount spent on non-beneficiary students and level of satisfaction

\begin{tabular}{|c|c|c|c|}
\hline \multirow{2}{*}{$\begin{array}{l}\text { On average amount spend on } \\
\text { children not enjoying free SHS }\end{array}$} & \multicolumn{2}{|c|}{ Satisfaction level of free SHS policy } & \multirow[t]{2}{*}{ Total } \\
\hline & High & Low & \\
\hline $\mathrm{GHC}(0-300)$ & 10 & 0 & 10 \\
\hline GHC (301-600) & 32 & 0 & 32 \\
\hline GHC (601 - 900) & 30 & 2 & 32 \\
\hline GHC $(901-1200)$ & 24 & 0 & 24 \\
\hline GHC (1201-1500) & 76 & 17 & 93 \\
\hline Total & 172 & 19 & 191 \\
\hline
\end{tabular}

$\chi^{2}=74.886 \quad P-$ value $=0.000$

\section{The effect of number of children of parents and the level of satisfaction}

Out of 237 respondents, 107 who had children from 1-3 had $94 \%$ high level of satisfaction and $6 \%$ had low level of satisfaction. Those who had a number of children between 4 and 5, 92 responded out of which $93 \%$ showed high level of satisfaction and 7\% showing low level of satisfaction. 18 parents also responded with 6 to 7 number of children. $61 \%$ showed high level of satisfaction and 39\% showed low level of satisfaction. In the last range of children which is 8 to 10 , parent consisting of 20 responded. $90 \%$ showed high level of satisfaction and $10 \%$ showed high level of satisfaction.

From the table 8 , the test is significant $(\mathrm{P}-$ value $=0.000<0.05)$. That is to say the number of children given by parents enjoying free SHS has an impact on the level of satisfaction.

Table 8:-test on number of children and parents level of satisfaction

\begin{tabular}{|l|l|l|l|}
\hline \multirow{2}{*}{ Number of Children } & Satisfaction level of free SHS policy & \multirow{2}{*}{ Total } \\
\cline { 2 - 3 } & High & Low & \\
\hline $1-3$ & 101 & 6 & 107 \\
\hline $4-5$ & 86 & 6 & 92 \\
\hline $6-7$ & 11 & 7 & 18 \\
\hline $8-10$ & 18 & 2 & 20 \\
\hline Total & 216 & 21 & 237 \\
\hline
\end{tabular}

$\chi^{2}=52.323 \quad P-$ value $=0.000$

\section{Discussion:-}

Education is important and a foundation to development with which our well-being hinges. It also helps to raise the status of the poor to richness. It is crucial to a person's productivity and enhances individual to seek economic opportunities and improves individual per capita income (Ozturk 2001).

McMahon (1999) explains that not only education help the individual to develop, it also helps the family as a unit in the society in terms of increased income potential which lessens poverty and enhance the living standard of the people in families and societies as a whole.

Single parenting is dominant with the data gathered among parents who were respondents. Because of concentration of responsibility which should have been a shared responsibility among couples, financial responsibilities are huge 
and we think it is another phenomenon that has influenced a high satisfaction and acceptability of the free SHS by parents in Asunafo South district.

Making an inference from Ozturk (2001) and McMahon (1999), the people of Asunafo south district are perceived to be poor. The academic qualifications of parents are low with JHS/Middle school certificate which is shown in the data influencing their occupation. Most parents are farmers and engage in subsistence farming. It is in this light that we think there is high satisfaction of parents in Asunafo South because free SHS has relieved them of financial stress.

Parents appreciate and accept the funding of the free SHS. They alluded to the fact that it has brought financial relieve. Lack of economic wealth or resources of parents as a result of low level of education and occupation influenced greatly their responses because cost of education is difficult for them to meet. This is evidenced in the amount they spend on non-beneficiaries and beneficiaries shown in table two above showing an average reduction of fees which may have crippled the poor from accessing education. Free SHS has brought reduction of fees which has also reduced the burden of parents. In conclusion parents in Asunafo South are happy with government solely funding the free SHS policy.

However, parents incur cost irrespective of the absorption of cost in SHS. This we think may be due to the fact that free SHS has incentivised parents to send their wards to the boarding schools and inadvertently incurring cost such as transportation, pocket monies for their wards and other provisions to complement students stay on campus.

Again, parents according to the results shown are satisfied with the free SHS policy because most parents said it has relieved them of financial stress. However with the few who were not satisfied indicated that the quality of education will be stifled which conforms to opponents views of the policy, that massive enrolment will pressurise exiting infrastructure including students' accommodation, classrooms and furniture etc.

\section{Conclusion and Recommendations:- \\ Conclusion}

The free SHS is liked by parents in Asunafo south district of the Brong Ahafo Region especially those with poor economic background. It has significantly reduced cost of schooling and increased enrolment.

However, the policy has not been able to cover all cost of parents. Parents have been motivated to send their children to school especially the boarding house which is also catered for by the government. This has brought other cost to parents in taking care of their ward. It may include; transportation, purchases of bag and baggage normally called trunk and chop boxes and pocket monies for little expenses in school. This points to and confirms the assertion by ISSER (2009) that free SHS is not absolute in terms of cost absorption.

\section{Recommendations}

The government must provide adequate infrastructure such as classrooms, dormitories, furniture to satisfy the few who questioned the free SHS on its quality.

Asunafo South District is noted to be a poor farming area with drought infrastructure and is evidenced in respondents' background. Junior high school (JHS) or Middle school leavers mostly farmers constitute majority of our respondents. A study should also be looked at with parents who may have affluent background in the rich schools and district to determine their satisfaction because opponents of free SHS are mostly parents with rich backgrounds whose position is to review free SHS to make it a pro poor policy.

\section{References:-}

1. Abdul-Rahaman, N., Rahaman, A. B. A., Ming, W., Ahmed, A. R., \& Salma, A. R. S. (2018). The Free Senior High Policy: An Appropriate Replacement to The Progressive Free Senior High Policy. International Journal of Education and Literacy Studies, 6(2), 26-33.

2. Alloush, M. (2010). Does free schooling fill the seats? Evaluating the changes in educational attainment associated with abolishing school fees in four African countries. Georgetown University.

3. Bhalotra, S., Harttgen, K., \&Klasen, S. (2015). The impact of school fees on schooling outcomes and the intergenerational transmission of education. University of Bristol, United Kingdom. 
4. Djangmah, J. (2011). Inequitable Access to Basic Education in Ghana: The Way Forward for Free Compulsory Universal Basic Education (FCUBE). CREATE Occasional Paper, 2.

5. https://www.graphic.com.gh/news/general-news/free-senior-high-school-rich-must-pay-participants-in-graphicbusiness-stanbic-forum-advocate.html

6. MOE (2017). Implementation of free senior high school education (free SHS)

7. McMahon, W. W. (1999).Education and development: Measuring the social benefits .New York: Oxford University Press

8. Osei, R. D., Owusu, G. A., Asem, F. E., \&Afutu-Kotey, R. L. (2009). Effects of capitation grant on education outcomes in Ghana. Accra, Institute of Social and Economic Research (ISSER).

9. Ozturk, I. (2001). The role of education in economic development: a theoretical perspective.

10. Partey P. A (2017). Access, Equity, Equality of free SHS: Farce or Reality? https://www. Researchgate.net/publication/ 320347085

11. NSDG (2017). The sustainable development goal report: United Nations. New York.

12. SDG (2017). Why they matter and how we can help. UN communications group (UNCG) Ghana. 